\section{Spatial Climate Justice and Green Infrastructure Assessment: A case study for the Huron River watershed, Michigan, USA}

Gl_Forum 2016, Vol.1

Page: 176-190

Full Paper

Corresponding Author:

chingwen.cheng@asu.edu

DOI: 10.1553/giscience2016_01_s176

\author{
Chingwen Cheng \\ Arizona State University, U.S.A
}

\begin{abstract}
Green infrastructure serves as a critical no-regret strategy to address climate change mitigation and adaptation in climate action plans. Climate justice refers to the distribution of climate change-induced environmental hazards (e.g., increased frequency and intensity of floods) among socially vulnerable groups. Yet no index has addressed both climate justice and green infrastructure planning jointly in the USA. This paper proposes a spatial climate justice and green infrastructure assessment framework to understand socialecological vulnerability under the impacts of climate change. The Climate Justice Index ranks places based on their exposure to climate change-induced flooding, and water contamination aggravated by floods, through hydrological modelling, GIS spatial analysis and statistical methodologies. The Green Infrastructure Index ranks access to biophysical adaptive capacity for climate change. A case study for the Huron River watershed in Michigan, USA, illustrates that climate justice hotspots are concentrated in large cities; yet these communities have the least access to green infrastructure. This study demonstrates the value of using GIS to assess the spatial distribution of climate justice in green infrastructure planning and thereby to prioritize infrastructure investment while addressing equity in climate change adaptation.
\end{abstract}

\title{
Keywords:
}

climate justice; green infrastructure; climate change-induced environmental hazards; climate change adaptation

\section{Introduction}

Climate change is associated with increased frequency and intensity of extreme weather (IPCC, 2014), such as two 1-in-500-years storm events occurring just15 years apart in Iowa in 1993 and 2008, and two 1-in-1,000-years storm events occurring 75 years apart in Phoenix in 1939 and 2014. Climate change-induced environmental hazards have aggravated the extent of impacts on the currently hazard-prone areas. Socially vulnerable groups who have fewer resources to manage risks are likely to suffer more. Social vulnerability can be a factor of demographic, social, economic and political status, in addition to urban context (e.g., age, 
gender, race, income, immigration status, education, occupation, social welfare and medical resources, housing density) (Walker \& Burningham, 2011). The concept of climate justice reveals uneven distribution of climate change-associated hazards and unequal capacity in socially vulnerable groups to mitigate hazards and adapt to the impacts. Green infrastructure has been recognized as a critical strategy in climate change adaptation (e.g., urban tree canopy for regulating micro climate and stormwater retention for regulating floods) as well as climate change mitigation (e.g., carbon sequestration) (Demuzere et al., 2014). However, the issue of equity in planning with regard to climate justice is often overlooked in green infrastructure planning.

Several efforts have been made to develop environmental justice indices, notably the newly released Environmental Justice Screening and Mapping Tool (EJSCREEN) (USEPA, 2015). Such indices have included measures of potential environmental exposure at the census-tract level using available environmental hazard sources for air pollution (e.g., PM2.5) and toxic or contaminated sites (e.g., USEPA Toxic Release Inventory). However, no index to date has taken into account the anticipated impacts of climate change on both local biophysical environments and populations. This paper proposes a climate justice assessment framework to incorporate social-ecological vulnerability assessment in the green infrastructure planning process by first examining areas with climate justice implications, and then evaluating the capacity of green infrastructure for climate change adaptation.

\section{Background}

Climate justice research applies an environmental justice framework to examine the racial and socio-economic disparities between people whose lives are affected by climate change. In recent decades, some environmental justice research has found strong relationships between poor environmental quality and socio-economic indicators such as race (e.g., African American minority) and the siting of hazardous facilities (Saha \& Mohai, 2005). For example, the metropolitan area of Detroit has long been an environmental injustice hotspot, where air pollution has posed threats to the health and academic performance of 3rd to 8th grade students in public schools (Mohai et al., 2011). Recent research has studied inequity of burdens from environmental hazards associated with climate change among socio-economic groups in local contexts, such as flooding hazards in the Boston metropolitan area (Cheng, 2013), drought (Smit \& Pilifosova 2006), and urban heat (Mitchell \& Chakraborty, 2014). As vulnerability and adaptive capacity vary from region to region and community to community, more studies on climate justice at the local level are needed.

Green infrastructure in this study is defined as an interconnected system that includes natural and man-made open spaces with the potential to serve as stormwater management and flood mitigation tools. Green infrastructure planning is linked to social-ecological systems. The ecological functions provide multiple ecosystem services (i.e. supporting, provisioning, regulating and cultural services, as defined by the Millennium Ecosystem Assessment in 2005); these services provide benefits and economic values to society (Hansen \& Pauleit, 2014). Applying green infrastructure to climate change planning is a win-win investment for society. Even if climate policy goals fail to be reached, other benefits of a green 
infrastructure will persist. Enhancing the green infrastructure is therefore considered a 'no regrets' strategy (Mees \& Driessen, 2011). Within the Huron watershed area, in 2012 the cities of Ann Arbor and Ypsilanti both developed climate action plans with primary focuses on climate change mitigation strategies for greenhouse gas reduction. Implementing green infrastructure was identified as a 'no regrets' strategy. In addition to the cities' own efforts, the Huron River Watershed Council (HRWC), a not-for-profit organization, assisted their watershed communities to develop 'community resilient' plans, taking climate-change impacts into consideration, to address water resources management (such as dam operations), water infrastructure, and in-stream flows. However, there is no mention of equity goals, or any supporting measures or vulnerability assessment in local climate change plans. The lack of equity planning is reflected in a recent study on policy-making with regard to climate change mitigation and adaptation plans that failed to include social justice goals and make equity an outcome compatible with environmental and economic goals of sustainability (Schrock et al., 2015).

In order to help counter the gaps in equity planning, this paper explores the evidence of climate injustice through a social-ecological vulnerability assessment and evaluates access to green infrastructure for climate change adaptation. The study aims to answer the following questions: 1) To what degree are climate change-induced and associated environmental hazards spatially correlated with socially vulnerable groups? 2) To what extent is green infrastructure available for climate change adaptation? This study applied the climate justice research framework to the Huron River watershed as a case study, focusing on water quality and flooding hazards associated with climate change.

\section{Study area}

The Huron River watershed drains more than 2,300 km2 covering seven counties in southeast Michigan, USA, including parts of Oakland and Wayne counties that border the core of the metropolitan area of Detroit. The watershed area has a population about 500,000 across 65 municipalities, including major cities such as Ann Arbor and Ypsilanti along the lower basin of the mainstream.

\section{Methods}

The social-ecological climate justice assessment framework integrated climate change impacts on flooding and the associated environmental hazards and environmental justice issues developed in this study. Several methodologies were included: 1) a climate-sensitivity study using a Flooding Hazard Index to determine the extent of the impacts of climate conditions (i.e., changes in temperature and precipitation); 2) a Climate Justice Index, developed by synthesizing flooding, environmental hazards, and social vulnerability indices; 3) a Green Infrastructure Index indicating available green infrastructure areas for climate change adaptation; 4) spatial analyses to examine potential hotspots of climate justice. 


\section{Climate sensitivity study}

A climate sensitivity study was conducted to understand the extent of climate change impacts on stream flows and associated floods. Based on temperature and precipitation data from 8 weather stations for the 30-year period 1981-2010, a total of 30 climate conditions in a 55year simulation (2011-2065) were generated. Simulated climate conditions include combinations of changing temperature $\left(0,+1,+2,+3,+4,+5^{\circ} \mathrm{C}\right)$ and precipitation $(0, \pm 10$, $\pm 20 \%)$ and served as climate data inputs for a hydrologic model, the Soil and Water Assessment Tool (SWAT). A 3-year warm-up period was applied to the calibration process of the SWAT model. Subsequently, 52 years of simulated streamflow outputs were used to construct a Flooding Hazard Index (FHI). A total of 57 sub-basins were delineated using the SWAT model. The methods for generating the simulated future climate data, using SWAT for a climate-sensitivity study, and the calibration and validation methodology for the SWAT model, are described in detail in Cheng (2013).

The FHI in this study was defined as the probability of daily streamflow higher than the bankfull discharge during a period of 52 years (i.e., 18,993 days):

$\mathrm{FHI}=($ Days when $\mathrm{Q}>$ Qbankfull $) /(18,993$ days $)$

Q: streamflow (SWAT output)

Qbankfull: stream bankfull volume (calculated based on a 2-year return period;described in detail in Reed et al., 2002)

The FHI used for the climate-sensitivity study serves as a proxy for potential change in the streamflow of each sub-basin resulting from changing climate conditions. The FHI neither employed frequency analysis methods (i.e., the method for defining a 100 -year flood) nor considered the magnitudes of floods in relation to current and future flood control devices (e.g., levees, dams).

\section{Climate Justice Index (CJI)}

The Climate Justice Index (CJI) assumed equal weights of all three indices - the Climate Change-Induced Flooding Hazard Index (CCFHI), the Environmental Hazard Index (EHI), and the Social Vulnerability Index (SoVI).

\section{Climate Change-Induced Flooding Hazard Index (CCFHI)}

The Climate Change-Induced Flooding Hazard Index (CCFHI) refers to potential increased flooding events, compared to the baseline condition, as a result of changing climate conditions. An increased FHI under any of the 30 climate conditions is considered to be 'Climate Change-Induced' flooding in this study. The CCFHI was constructed based on the subtraction of the FHI value in all climate conditions from the baseline, and was categorized into a five-point scale (0: zero increase; $1:+0-1 \%, 2:+1-2 \%, 3:+2-3 \%, 4:+3-4 \%, 5$ : $>+4 \%)$. Finally, the CCFHI for the sub-basin unit was converted for the census-tract unit using area proportion weighting. 


\section{Environmental Hazard Index (EHI)}

The Environmental Hazard Index (EHI) serves as a proxy for water quality associated with environmental hazard sources, assuming that all environmental hazard sites are susceptible to direct and indirect sources for both surface and underground water pollution in each hydrologic sub-basin unit. The EHI was constructed by integrating both environmental hazard sites and stream-reach data; equal weights for all types of environmental hazard data were assumed (Table 1). The EHI does not, however, include ecological and human risk assessment.

Table 1: List of environmental hazard sites collected for this study

\begin{tabular}{|c|c|c|c|}
\hline Names & Description & $\begin{array}{l}\text { Number of } \\
\text { samples }\end{array}$ & Sources \\
\hline $\begin{array}{l}\text { Toxic Release } \\
\text { Inventory (TRI) } \\
\text { facilities }\end{array}$ & $\begin{array}{l}\text { Facilities that release } \\
\text { hazardous air \& water } \\
\text { emissions }\end{array}$ & 37 & $\begin{array}{l}\text { US Environmental Protection } \\
\text { Agency (USEPA) } 2010\end{array}$ \\
\hline Superfund sites & National Priority List & 3 & $\begin{array}{l}\text { USEPA, } 66 \text { NPL sites in Michigan, } \\
\text { updated May } 2015\end{array}$ \\
\hline Landfill & $\begin{array}{l}\text { Landfills (section } 115 \\
\text { accepting active) }\end{array}$ & 0 & $\begin{array}{l}\text { Michigan Department of } \\
\text { Environmental Quality (MDEQ) }\end{array}$ \\
\hline Hazardous waste & $\begin{array}{l}\text { Hazardous Waste - } \\
\text { Treatment, Storage \& } \\
\text { Disposal (TSD) }\end{array}$ & 13 & USEPA \\
\hline Brownfield sites & Section 20112a & 236 & MDEQ Part 201 inventory list \\
\hline LUST & $\begin{array}{l}\text { Part } 213 \text { Leaking } \\
\text { Underground Storage Tanks } \\
\text { (LUST) }\end{array}$ & 703 & $\begin{array}{l}\text { MDEQ. Include both active and } \\
\text { closed leaking storage tanks }\end{array}$ \\
\hline Oil and gas wells & Surface wells & 389 & MDEQ \\
\hline $\begin{array}{l}\text { Formerly Used } \\
\text { Defense Sites }\end{array}$ & $\begin{array}{l}\text { Locations from the Formerly } \\
\text { Used Defense Sites Program }\end{array}$ & 4 & US Army Corp of Engineers \\
\hline $\begin{array}{l}\text { Risk-Screening } \\
\text { Environmental } \\
\text { Indicators (RSEI) } \\
\text { polluted stream } \\
\text { reach }\end{array}$ & $\begin{array}{l}\text { TRI point source pollution at } \\
\text { reach level defined by the US } \\
\text { Geological Survey National } \\
\text { Hydrography Dataset }\end{array}$ & 258 & $\begin{array}{l}\text { USEPA RSEI Microdata } 2010 ; \\
\text { Detailed methodology for water } \\
\text { pollution simulation refers to } \\
\text { USEPA RSEI Model }\end{array}$ \\
\hline
\end{tabular}

The EHI was constructed in several steps. First, the density of the environmental hazard sites in the sub-basin was calculated as the number of environmental hazard sites per square kilometre (excluding TRI facilities, as they are included in the RSEI modelling). Second, the total pollution concentration for each stream reach was averaged for each sub-basin. Third, both the density and RSEI indicators were normalized using min-max methodology, assigning the maximum value as 1 and minimum value as 0 , and all values were divided by the range. Fourth, the two normalized indicators were summed and categorized into a five- 
point scale using natural breaks. Finally, the EHI from each sub-basin unit was converted for the census-tract units by using area proportion weighting.

\section{Social Vulnerability Index (SoVI)}

Socially vulnerable groups can be defined by demographic characteristics, socio-economic indicators, access to medical and social welfare, housing density, and occupations that depend heavily on natural resources (Cutter et al., 2003). The Social Vulnerability Index (SoVI) is a benchmark for measuring vulnerability using a systematic and quantitative approach. It has been used successfully in several national and regional social vulnerability studies, and significant trends across temporal and spatial distributions were found in the United States (Cutter et al., 2003; Borden et al., 2007). There are 33 socio-economic indicators in 220 census tracts in the Huron River watershed, including people who are female, children, the elderly, members of an ethnic minority, migrants, large families, renters, and people on a low income, who are below the poverty level, who are unemployed, who are employed in service- and agriculture-related jobs, who have limited access to hospital and medical services, who are receiving social benefits and social medical care, and who live in urban areas (Table 2). Hospital data was from Southeast Michigan Council of Governments (SEMCOG), 2015. Census data was collected from the US Census Bureau's American Community Survey 2013, which was the most recent data available at the time of the study. This study does not include temporal change of social vulnerability patterns. The SoVI was constructed using a variety of statistical methods: normalization, standardization, principal component analysis using a varimax rotation and Kaiser criterion for component selection, Pearson's correlation between components, and synthesizing components according to their respective positive or negative impacts on vulnerability. Finally, the SoVI scores were categorized by quintile and represented in a five-point scale, 5 being the most socially vulnerable (= top $20 \%$ of the sampled population).

Table 2: Social vulnerability variables: descriptive statistics ( $N=220)$

\begin{tabular}{lllllll}
\hline Variable & Variable Descriptions & Min. & Max. & Mean & S.D. & Variance \\
\hline MEDAGE & Median Age & 16.50 & 53.40 & 39.14 & 6.89 & 47.41 \\
QBLACK & Percent African American & 0.00 & 68.27 & 8.09 & 12.53 & 156.94 \\
QNAMER & Percent Native American & 0.00 & 1.99 & 0.24 & 0.40 & 0.16 \\
QASIAN & $\begin{array}{l}\text { Percent Asian and Hawaiian } \\
\text { Qslanders }\end{array}$ & 0.00 & 42.59 & 4.80 & 7.44 & 55.30 \\
QSPANISH & Percent Hispanic & 0.00 & 14.90 & 3.33 & 2.72 & 7.42 \\
QPISLAND & Percent pacific islanders & 0.00 & 2.39 & 0.03 & 0.18 & 0.03 \\
QKIDS & $\begin{array}{l}\text { Percent of population } \\
\text { under 5 yrs old }\end{array}$ & 0.00 & 17.20 & 5.46 & 2.67 & 7.13 \\
QPOP65O & $\begin{array}{l}\text { Percent of population 65 } \\
\text { and over }\end{array}$ & 0.00 & 36.70 & 11.91 & 5.60 & 31.35 \\
PPUNIT & $\begin{array}{l}\text { Average number of people } \\
\text { per household }\end{array}$ & 1.51 & 4.46 & 2.55 & 0.41 & 0.17 \\
QRENTER & $\begin{array}{l}\text { Percent of renter-occupied } \\
\text { housing units }\end{array}$ & 0.80 & 100.00 & 27.73 & 26.96 & 726.82
\end{tabular}




\begin{tabular}{|c|c|c|c|c|c|c|}
\hline NRRESPC & $\begin{array}{l}\text { Per capita residents in } \\
\text { nursing homes }\end{array}$ & 0.00 & 7.52 & 0.23 & 0.89 & 0.79 \\
\hline QFEMALE & Percent female population & 36.50 & 79.30 & 50.79 & 3.91 & 15.33 \\
\hline QFHH & $\begin{array}{l}\text { Percent female-headed } \\
\text { households, no spouse } \\
\text { present }\end{array}$ & 0.00 & 35.10 & 9.67 & 5.84 & 34.06 \\
\hline HOSPTPC & $\begin{array}{l}\text { Per capita number of } \\
\text { community hospitals }\end{array}$ & $\begin{array}{l}0.00 \mathrm{E}+ \\
00\end{array}$ & $\begin{array}{l}1.02 \mathrm{E}- \\
03\end{array}$ & $\begin{array}{l}3.41 \mathrm{E}- \\
04\end{array}$ & $1.91 \mathrm{E}-04$ & $0.00 \mathrm{E}+00$ \\
\hline HODENT & $\begin{array}{l}\text { Number of housing units } \\
\text { per square mile }\end{array}$ & 12.18 & 6645.43 & 904.62 & 1103.54 & $1.22 \mathrm{E}+06$ \\
\hline PERCAP & $\begin{array}{l}\text { Per capita income (in } \\
\text { dollars, 2013) }\end{array}$ & $\begin{array}{l}10,141 \\
00\end{array}$ & $\begin{array}{l}85,173 \\
00\end{array}$ & $\begin{array}{l}33,187 \\
75\end{array}$ & $10,510.54$ & $1.10 \mathrm{E}+08$ \\
\hline MHSEVAL & $\begin{array}{l}\text { Mean value of owner - } \\
\text { occupied housing units }\end{array}$ & $\begin{array}{l}16,600 \\
00\end{array}$ & $\begin{array}{l}644,700 \\
.00\end{array}$ & $\begin{array}{l}191,135 \\
.89\end{array}$ & $91,131.93$ & $8.31 \mathrm{E}+09$ \\
\hline M_C_RENT & Mean contract rent & 338.00 & 1923.00 & 851.05 & 281.21 & 7.91E+04 \\
\hline PHYSICN & $\begin{array}{l}\text { Number persons per } \\
100,000 \text { population } \\
\text { employed as healthcare } \\
\text { practitioners and in } \\
\text { technical occupations }\end{array}$ & 0.00 & $\begin{array}{l}19,524 . \\
96\end{array}$ & $\begin{array}{l}6,809.5 \\
1\end{array}$ & $3,371.80$ & $1.14 \mathrm{E}+07$ \\
\hline QMIGRA & $\begin{array}{l}\text { Percent foreign born } \\
\text { citizens immigrating } \\
\text { between } 1990 \text { and } 2000\end{array}$ & 0.00 & 48.50 & 5.49 & 8.87 & 78.66 \\
\hline QCVLUN & $\begin{array}{l}\text { Percent civilian } \\
\text { unemployment }\end{array}$ & 0.00 & 40.50 & 9.51 & 4.77 & 22.72 \\
\hline QRICH & $\begin{array}{l}\text { Percent of households } \\
\text { earning } \$ 100,000 \text { or more }\end{array}$ & 0.00 & 78.77 & 29.68 & 15.98 & 255.46 \\
\hline QPOVTY & $\begin{array}{l}\text { Percent living below } \\
\text { poverty line }\end{array}$ & 0.30 & 69.00 & 11.69 & 11.62 & 135.03 \\
\hline QMOBIL & $\begin{array}{l}\text { Percent of housing units } \\
\text { that are mobile homes }\end{array}$ & 0.00 & 75.80 & 5.29 & 11.46 & 131.40 \\
\hline QED12LES & $\begin{array}{l}\text { Percent of population } 25 \\
\text { years or older with no high } \\
\text { school diploma }\end{array}$ & 0.00 & 31.50 & 6.76 & 4.58 & 20.98 \\
\hline QCVLBR & $\begin{array}{l}\text { Percent of population } \\
\text { participating in the labour } \\
\text { force }\end{array}$ & 33.29 & 75.07 & 53.80 & 6.31 & 39.81 \\
\hline QFEMLBR & $\begin{array}{l}\text { Percent females } \\
\text { participating in the labour } \\
\text { force }\end{array}$ & 33.10 & 100.00 & 62.71 & 8.55 & 73.14 \\
\hline QAGRI & $\begin{array}{l}\text { Percent employment in } \\
\text { farming, fishing and } \\
\text { forestry }\end{array}$ & 0.00 & 5.40 & 0.41 & 0.86 & 0.74 \\
\hline QTRAN & $\begin{array}{l}\text { Percent employed in } \\
\text { transportation, } \\
\text { communications, and other } \\
\text { public utilities }\end{array}$ & 0.00 & 17.10 & 3.76 & 3.30 & 10.92 \\
\hline QSERV & $\begin{array}{l}\text { Percent employed in service } \\
\text { industries }\end{array}$ & 0.00 & 44.90 & 16.11 & 7.03 & 49.47 \\
\hline
\end{tabular}




\begin{tabular}{|c|c|c|c|c|c|c|}
\hline QHCSERV & $\begin{array}{l}\text { Percent civilian employed in } \\
\text { educational services, and } \\
\text { health care and social } \\
\text { assistance }\end{array}$ & 0.00 & 74.50 & 28.60 & 12.07 & 145.65 \\
\hline QURBAN & Percent urban population & 0.00 & 100.00 & 84.54 & 28.85 & 832.05 \\
\hline QSSBEN & $\begin{array}{l}\text { Percent of population } \\
\text { collecting social security } \\
\text { benefits }\end{array}$ & 0.00 & 70.83 & 26.40 & 9.60 & 92.13 \\
\hline
\end{tabular}

\section{Green Infrastructure Index (GII)}

Based on the most recent land-use data (2010) provided by the Southeast Michigan Council of Governments (SEMCOG), green infrastructure includes agricultural land, recreational spaces, golf courses, cemeteries, parks and open spaces, and bodies of water. The green infrastructure land use areas occupy a total of $25.5 \%$ of the watershed area; the rest of the land is considered as built-up areas, including for residential, industrial, transportation, office, retail, medical and parking purposes, and vacant lots. The Green Infrastructure Index (GII) was constructed based on the hydrological connectivity of the green infrastructure in each sub-basin unit. Several steps were taken: (1) calculation of the fraction of green infrastructure area for each sub-basin area; (2) calculation of area proportion of sub-basin unit within the census-tract unit area; (3) conversion of the sub-basin unit to the census-tract unit by summing the multiplied fractions from steps (1) and (2); (4) creation of an index with a fivepoint scale based on the natural breaks of the values calculated in step (3), 1 being the lowest and 5 the highest score in the census-tract unit.

\section{Statistical and spatial analyses}

IBM SPSS version 21 was used for constructing the SoVI and for carrying out both the descriptive analysis and Pearson's correlation. The Getis-Ord Gi Hot Spot Analysis in spatial statistics within ESRI ArcGIS 10.1 was applied for analysing the spatial distribution of one variable. ArcGIS 10.1 was also used for mapping. Finally, a bivariate cluster analysis for analysing the spatial distribution patterns of two variables was conducted using the GeoDa system developed by the Arizona State University GeoDa Center.

\section{Results}

\section{Climate change impact scenarios}

The climate-sensitivity study revealed a wide range of sensitivity, as shown by the FHI scores for 30 climate conditions and 57 sub-basins. For example, sub-basin 7 demonstrates the highest sensitivity to climate change with a difference of $13.8 \%$ between the lowest and highest probability of flooding hazards, while sub-basin 45 had a range of $2.5 \%$ (Figure 1). The average of all climate sensitivity results is $0.7 \%(n=1710)$. In general terms, an increase in temperature will decrease the FHI, while increased precipitation will increase the FHI in 
the Huron River watershed. The upper stream is sensitive to climate change-induced floods, and the climate change impacts expand predominantly along the main channel, with a few first-order stream-reach sub-basins, at the higher climate change impact conditions.

Based on the results of the climate sensitivity study, two climate change impact scenarios are identified for further demonstration: a lower climate change impact condition, with increases of $2^{\circ} \mathrm{C}$ in mean temperature and $10 \%$ in mean precipitation; a one, with increases of $1^{\circ} \mathrm{C}$ in mean temperature and $20 \%$ in mean precipitation.

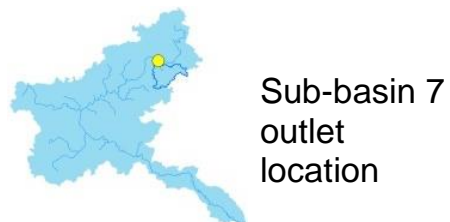

\section{Sub-basin 7}

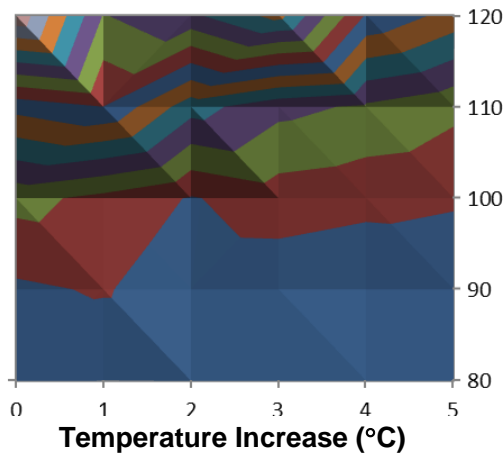

\section{FHI}

$=13.00 \%-14.00 \%$

$=12.00 \%-13.00 \%$

$=11.00 \%-12.00 \%$

$=10.00 \%-11.00 \%$

= $9.00 \%-10.00 \%$

$=8.00 \%-9.00 \%$

$=7.00 \%-8.00 \%$

$=6.00 \%-7.00 \%$

$=5.00 \%-6.00 \%$

- $4.00 \%-5.00 \%$

$=3.00 \%-4.00 \%$

$2.00 \%-3.00 \%$

= $1.00 \%-2.00 \%$

$=0.00 \%-1.00 \%$

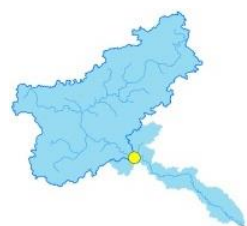

Sub-basin

45 outlet location

\section{Sub-basin45}

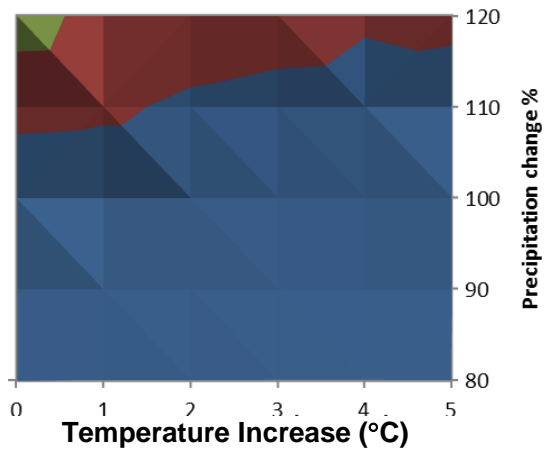

Figure 1: Climate sensitivity study in the Huron River watershed showing varied response to the 30 climate conditions of the Flooding Hazard Index (FHI)

\section{Climate Justice Index}

Figure 2 illustrates the results of the three indices before being synthesized into the single Climate Justice Index (CJI). The CCFHI for the lower climate change impact condition shows most watershed increases to be of $1 \%$ on the FHI, except for the Wixom area, where increases could be up to $3 \%$ (Figure 2a). Wixom is highly sensitive to climate change-induced flooding, with a significant increase of $4 \%$ and more for the FHI, while Ann Arbor increases up to $2 \%$ under the higher impact condition (Figure $2 \mathrm{~b}$ ). The EHI illustrates a high potential threat for climate change-associated water pollution ( $\mathrm{EHI}=4$ or 5 ) around the cities of Wixom, Ann Arbor and Ypsilanti (Figure 2c). The SoVI illustrates a relatively high level of social vulnerability (SoVI=4 or 5) near the same cities (Figure $2 \mathrm{~d}$ ). 


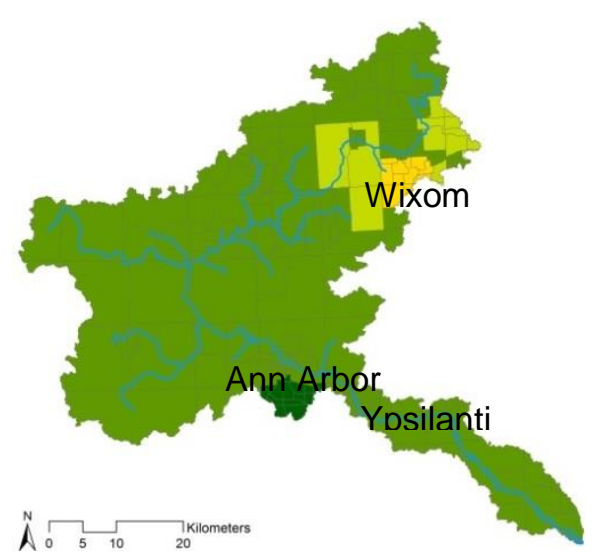

(a) CCFHI: Lower Climate Change Impact

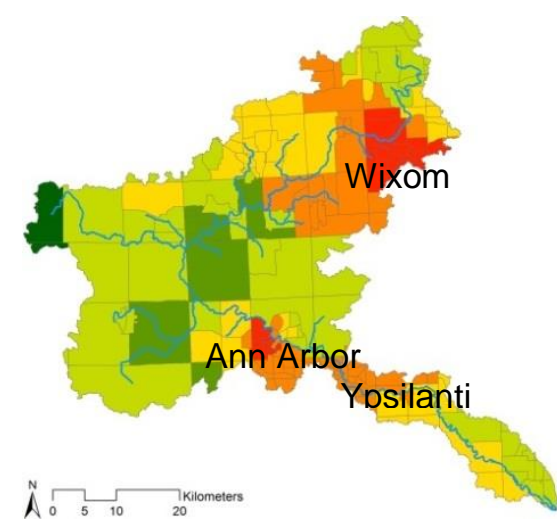

(c) $\mathrm{EHI}$

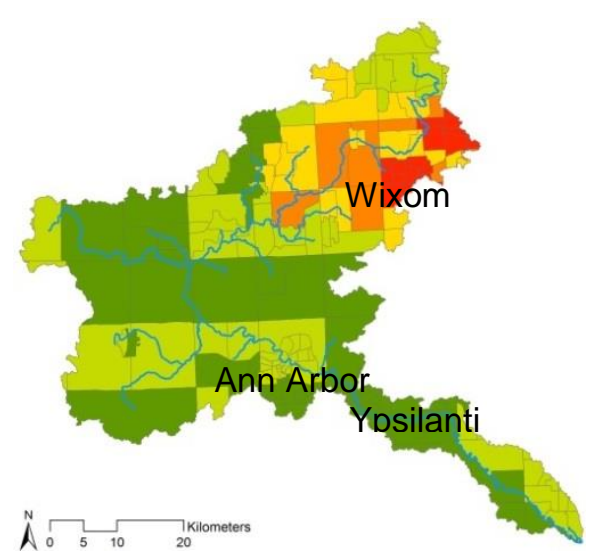

(b) CCFHI: Higher Climate Change Impact

Figure 2: (a) and (b) Climate Change-Induced Flooding Hazard Index (CCFHI) at lower and higher climate change impacts, 0 : zero increase, 1: $+0-1 \%, 2:+1-2 \%, 3:+2-3 \%, 4:+3-4 \%, 5:>+4 \%$; (c) Environmental Hazard Index (EHI), 5 being the highest and 1 being the lowest exposure to environmental hazards, and 0 being no pollution source present; (d) Social Vulnerability Index (SoVI), 5 being the most socially vulnerable ( $20 \%$ of total population), 0 being no data

Figure 3 illustrates the synthesized CJI, comparing the baseline conditions at zero flooding increase in current climate conditions with lower- and higher-impact climate change scenarios. The results demonstrate that the cities of Wixom, Ann Arbor and Ypsilanti are areas likely to face climate injustice $(\mathrm{CJI}=3)$ in the baseline conditions when no climate change condition occurs and there is zero increase in the probability of climate changeinduced flooding (Figure 3a). When facing climate change impacts of increased flooding hazards, the Wixom area is highly susceptible to climate injustice $(\mathrm{CJI}=4)$, even under the lower climate change impact scenario (Figure 3b). In the higher-impact scenario, more census tracts with higher social vulnerability around the Wixom and Ann Arbor areas would face more challenges of climate change-induced environmental hazards and would consequently encounter a higher level of climate injustice (CJI=4 and 5) (Figure 3c). 


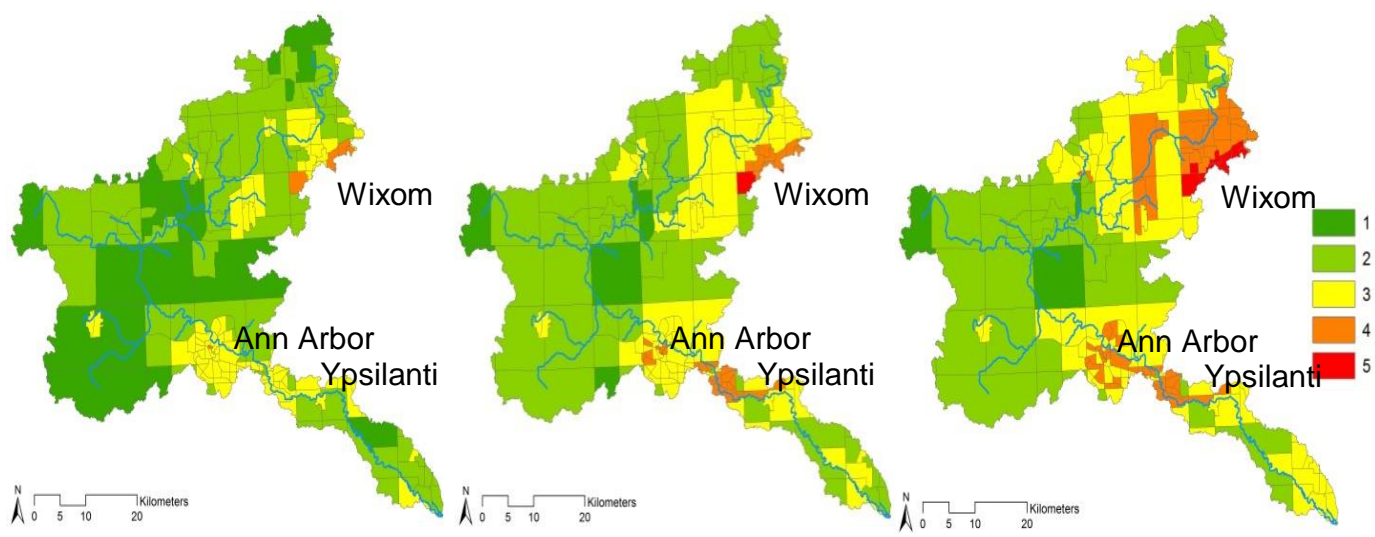

(a) Baseline

b) Lower Climate Change Impact

(c) Higher Climate Change Impact

Figure 3. Climate Justice Index; 1 indicates the least and 5 indicates the most potential for climate injustice in (a) baseline, (b) lower climate change impact, and (c) higher climate change impact scenarios

To further analyse the spatial distribution of climate justice issues, Figure 4 demonstrates the results of Hot Spot Analysis of the baseline condition compared to the lower and higher climate change impact scenarios. The red census tracts are those with higher CJI rankings, which tend to be clustered together; blue shows lower CJI clusters. The cities of Ann Arbor and Ypsilanti are two significant climate injustice areas in baseline conditions (Figure 4a). A comparison of the lower and higher climate change impacts scenarios reveals a significant increase in the size of the high CJI cluster in the Wixom, implying high sensitivity to changes in climate conditions in this area (Figure $4 \mathrm{~b}$ and $4 \mathrm{c}$ ).

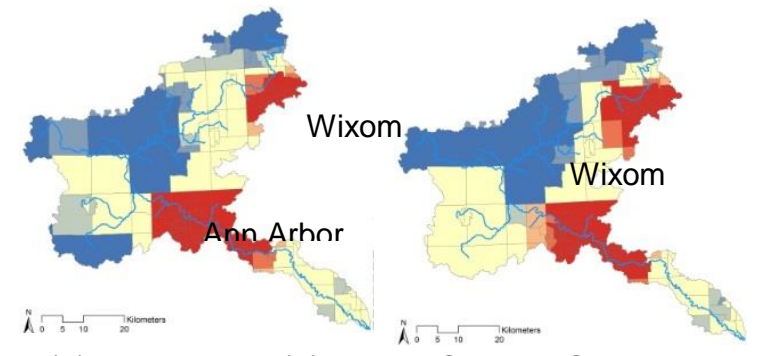

(a) Baseline

(b) Lower Climate Change Impact

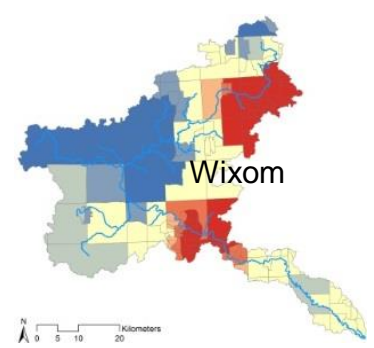

(c) Higher Climate Change Impact

Figure 4: Spatial analyses illustrating Climate Justice Index hotspots for (a) baseline, (b) lower climate change impact, and (c) higher climate change impact scenarios

\section{Green Infrastructure Index (GII)}

This study focuses on the hydrological connectivity of the green infrastructure for mitigating climate change-induced flooding hazards and water pollution. Most green infrastructure land-use areas are concentrated in sub-basins in the middle stream on the west side of the 
watershed. Wixom, Ann Arbor and Ypsilanti are in sub-basins that have less extensive areas of green infrastructure (Figure 5a). The Green Infrastructure Index (GII), shown in relation to census-tract units, highlighted the same spatial patterns for the distribution of green infrastructure (Figure 5b), where green indicates the most extensive hydrologically-connected green infrastructure $(\mathrm{GII}=1)$ and red the least availability of green infrastructure (GII=5). The hotspot analysis further confirmed the spatial distribution of clusters of GII cold spots on the west side of the watershed, and of hotspots, for high deficiency of green infrastructure, around Wixom, Ann Arbor and Ypsilanti (Figure 5c).

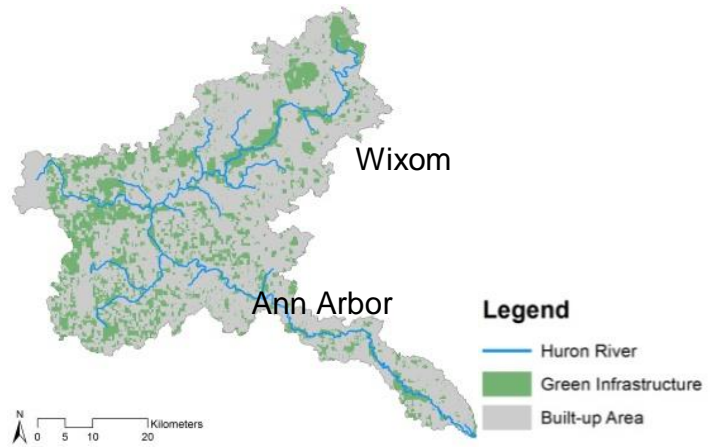

(a) Extent of green infrastructure areas in sub-basin unit

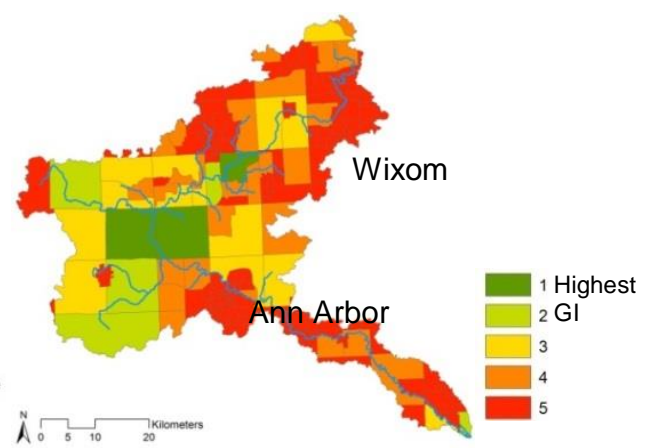

(b) Green Infrastructure Index (GII) in census tract units

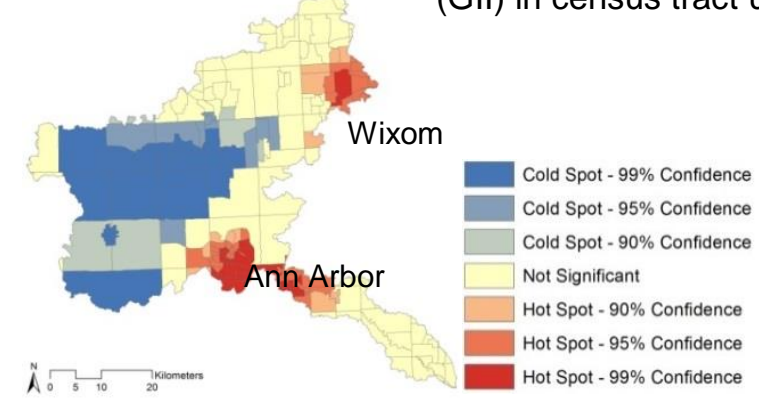

(c) Gll clusters pattern analysis

Figure 5: (a) distribution of green infrastructure land-use areas in sub-basin units; (b) Green Infrastructure Index (GII): 1 indicates the highest and 5 indicates the lowest amount of hydrologicallyconnected green infrastructure; (c) Gll clusters pattern analysis illustrates cold spots and hotspots

\section{CJI and GII Spatial relationship}

To further examine the spatial relationship between the CJI and GII, a bivariate Moran's I test was carried out, the results of which suggest a significant positive effect (Moran's I $=0.35$ ): high values on the CJI index tend to be spatially near high values for the GII (Figure 6). This finding indicates that currently areas with a high level of climate injustice (CJI=5) coincide with high deficiency of green infrastructure (GII=5). 


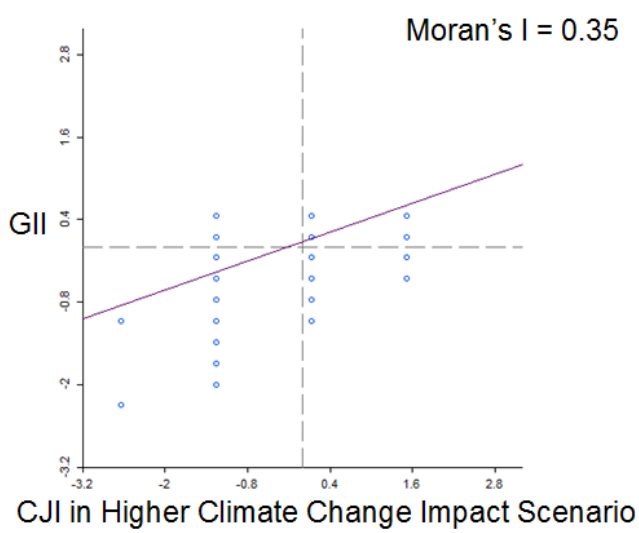

Figure 6: Results of spatial statistics (bivariate Moran's I test) for CJl in higher climate change impact scenario and GIl suggest a significant positive cluster pattern of high climate injustice areas tending to correlate with high deficiency of green infrastructure

\section{Discussion}

This study applied a Climate Justice Assessment framework incorporating a social-ecological vulnerability assessment under various climate change impact scenarios, and revealed empirical evidence of Climate Justice concerns, particularly around the cities of Wixom, Ann Arbor and Ypsilanti in the Huron River watershed. In particular, under the higher climate change impact conditions, climate change-induced flooding hazards become more prominent in the Wixom area, along with a higher level of potential water pollution from environmental hazard sites. Those areas with higher environmental vulnerability are also the areas where more socially vulnerable groups reside. However, the Climate Justice Index hotspots match where the Green Infrastructure Index hotspots are, indicating that the potential biophysical capacity of green infrastructure (Matthews et al., 2015) for climate change adaptation in the Wixom, Ann Arbor and Ypsilanti is currently at a minimum.

The Cities of Ann Arbor and Ypsilanti recently (2012) developed their Climate Action Plans and indicated the development of green infrastructure as one of their 'no-regret' strategies. In addition, the Huron River Watershed Council (HRWC) has assisted watershed communities, including in the Ann Arbor and Ypsilanti areas, in building resiliency through the understanding of potential climate change impacts on the watershed management systems as well as by outlining strategies to cope with climate change. The Ann ArborYpsilanti area therefore currently has the social-political feasibility to increase its green infrastructure capacity for climate change adaptation (Matthews et al., 2015), and a great potential to address the issue of climate justice in the green infrastructure planning process.

On the other hand, the City of Wixom has not yet made plans for climate change. During the course of this study, the HRWC has reached out to Wixom with regards to the climate change adaptation efforts in the area, yet no action items have been developed. The Wixom area currently has both low biophysical and social-political feasibility to increase green infrastructure capacity for climate change adaptation, making Wixom the area with the 
highest climate injustice, with regards to the impacts of climate change, in the entire watershed region.

\section{Conclusions}

This study has demonstrated empirical evidence of a lack of green infrastructure capacity to address climate justice in relation to potential impacts from climate change-induced flooding and water quality impairment in the Cities of Wixom, Ann Arbor and Ypsilanti in the Huron River watershed. This place-based climate justice assessment framework combined with biophysical and social-political feasibility assessment of green infrastructure capacity for climate change adaptation can be applied in other watershed areas. The identification of climate justice hotspots under a range of climate change conditions could inform decisionmaking in community planning to prioritize green infrastructure for climate change adaptation in those areas that have the greatest social needs.

\section{Acknowledgements}

This work was supported by the University of Michigan Water Center, a centre of the Graham Sustainability Institute. The Water Center is supported by funds from the Fred A. and Barbara M. Erb Family Foundation and the University of Michigan. The author would like to thank Co-Principal Investigator Dr. Paul Mohai for his inputs on overall research; CoInvestigator Dr. Margaret Kalcic for leading hydrological modelling work with project staff $\mathrm{Xin} \mathrm{Xu}$ and Yu-Chen Wang; Dr. Y.C. Ethan Yang for providing the projected climate dataset, and for feedback on the climate sensitivity and hydrological modelling work; and Rebecca Esselman and Ric Lawson along with the director and staff of the Huron River Watershed Council for their enthusiastic and constructive involvement throughout the project.

\section{References}

Borden, K. A., Schmidtlein, M. C., Emrich, C. T., Piegorsch, W. W., \& Cutter, S. L. (2007).

Vulnerability of U.S. cities to environmental hazards. Journal of Homeland Security and

Emergency Management, 4(2).

Cheng, C. (2013). Social vulnerability, green infrastructure, urbanization and climate change-induced

flooding: A risk assessment for the Charles River watershed, Massachusetts, USA. Dissertation.

University of Massachusetts, Amherst.

City of Ann Arbor (2012). Climate Action Plan. City of Ann Arbor.

City of Ypsilanti (2012). Climate Action Plan. City of Ypsilanti.

Cutter, S. L., Boruff, B. J., \& Shirley, W. (2003). Social vulnerability to environmental hazards. Social

Science Quarterly (Blackwell Publishing Limited), 84(2), 242-261.

Demuzere, M., Orru, K., Heidrich, O., Olazabal, E., Geneletti, D., Orru, H., Bhave, A. G., Mittal, N., Feliu, E., \& Faehnle, M. (2014). Mitigating and adapting to climate change: Multi-functional and 
multi-scale assessment of green urban infrastructure. Journal of Environmental Management, 146(0), 107-115. doi: 10.1016/j.jenvman.2014.07.025

Hansen, R., \& Pauleit, S. (2014). From Multifunctionality to Multiple Ecosystem Services? A Conceptual Framework for Multifunctionality in Green Infrastructure Planning for Urban Areas. AMBIO, 43(4), 516-529. doi: 10.1007/s13280-014-0510-2

Huron River Watershed Council. Climate-Resilient Communities, Retrieved December 12, 2015 http://www.hrwc.org/our-work/programs/making-climate-resilient-communities/

IPCC. (2014). Summary for Policymakers. In C. B. Field, V. R. Barros, D. J. Dokken, K. J. Mach, M. D. Mastrandrea, T. E. Bilir, M. Chatterjee, K. L. Ebi, Y. O. Estrada, R. C. Genova, B. Girma, E. S. Kissel, A. N. Levy, S. MacCracken, P. R. Mastrandrea \& L. L. White (Eds.), Climate Change 2014: Impacts, Adaptation, and Vulnerability. Part A: Global and Sectoral Aspects. Contribution of Working Group II to the Fifth Assessment Report of the Intergovernmental Panel on Climate Change (pp. 1-32). Cambridge, United Kingdom, and New York, NY, USA: Cambridge University Press.

Matthews, T., Lo, A. Y., \& Byrne, J. A. (2015). Reconceptualizing green infrastructure for climate change adaptation: Barriers to adoption and drivers for uptake by spatial planners. Landscape and Urban Planning, 138, 155-163. doi: 10.1016/j.landurbplan.2015.02.010

Mees, H.-L. P., \& Driessen, P. P. J. (2011). Adaptation to climate change in urban areas: Climategreening London, Rotterdam, and Toronto. Climate Law, 2(2), 251-280. doi: 10.3233/CL-2011036

Mitchell, B. C., \& Chakraborty, J. (2014). Urban Heat and Climate Justice: A Landscape of Thermal Inequity in Pinellas County, Florida. Geographical Review, 104(4), 459-480. doi: 10.1111/j.19310846.2014.12039.x

Mohai, P., Kweon, B.-S., Lee, S., \& Kerry, A. (2011). Air Pollution Around Schools Is Linked To Poorer Student Health And Academic Performance. Health Affairs, 30(5).

Reed, S., Johnson, D., \& Sweeney, T. (2002). Application and national geographic information system database to support two-year flood and threshold runoff estimates. Journal of Hydrologic Engineering, 7(3), 209-219. doi:10.1061/(ASCE)1084-0699(2002)7:3(209)

Saha, R., \& Mohai, P. (2005). Historical context and hazardous waste facility siting: Understanding temporal patterns in Michigan. Social Problems, 52(4), 618-648. doi: 10.1525/sp.2005.52.4.618

Schrock, G., Bassett, E. M., \& Green, J. (2015). Pursuing Equity and Justice in a Changing Climate: Assessing Equity in Local Climate and Sustainability Plans in U.S. Cities. Journal of Planning Education and Research, 35(3), 282-295. doi: 10.1177/0739456x15580022

Smit, B., \& Wandel, J. (2006). Adaptation, adaptive capacity and vulnerability. Global Environmental Change, 16(3), 282-292. doi: 10.1016/j.gloenvcha.2006.03.008

USEPA. EJSCREEN: Environmental Justice Screening and Mapping Tool, Retrieved September 15, 2015, from http://www.epa.gov/ejscreen

Walker, G., \& Burningham, K. (2011). Flood risk, vulnerability and environmental justice: Evidence and evaluation of inequality in a UK context. Critical Social Policy, 31(2), 216-240. doi: $10.1177 / 0261018310396149$ 